\title{
Beyond the Bioorthogonal Inverse-Electron-Demand Diels-Alder Reactions of Tetrazines: 2-Pyrone-Functionalized Fluorogenic Probes
}

\author{
Gergely B. Cserép*a \\ Krisztina Németh ${ }^{\mathrm{a}}$ \\ Ágnes Szatmária \\ Flóra Horváth ${ }^{a}$ \\ Tímea Imre ${ }^{\mathrm{b}}$ \\ Krisztina Németh ${ }^{\mathrm{b}}$ \\ Péter Kele*a \\ ${ }^{a}$ Chemical Biology Research Group, Institute of Organic Chemistry, \\ ELKH Research Centre for Natural Sciences, Magyar Tudósok Krt 2., \\ 1117 Budapest, Hungary \\ cserep.balazs.gergely@ttk.hu \\ kele.peter@ttk.hu \\ b MS Metabolomics Research Group, Centre for Structural Study, \\ ELKH Research Centre for Natural Sciences, Magyar Tudósok Krt 2., \\ 1117 Budapest, Hungary
}

Published as part of the

Special Issue in memory of Prof. Ferenc Fülöp

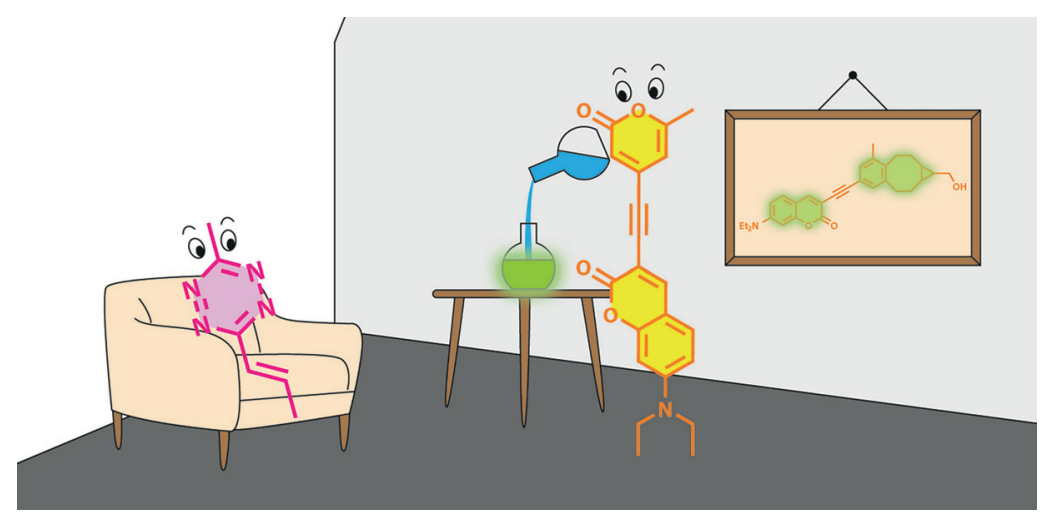

Received: 15.10.2021

Accepted after revision: 03.01.2022

Published online: 04.02 .2022

DOI: 10.1055/a-1761-4672; Art ID: ss-2021-t0622-st

License terms: CCO

(c) 2022. The Author(s). This is an open access article published by Thieme under the terms of the Creative Commons Attribution-NonDerivative-NonCommercial-License, permitting copying and reproduction so long as the original work is given appropriate credit. Contents may not be used for commercial purposes or adapted, remixed, transformed or built upon. (https://creativecommons.org/licenses/by-nc-nd/4.0/)

Abstract The applicability of pyrones as a bioorthogonal platform was explored in inverse-electron-demand Diels-Alder (IEDDA) reactions with a strained cyclooctyne. Studies showed that the pyrones are indeed suitable for IEDDA reactions under physiological conditions. Furthermore, the stable pyrone moiety could be utilized to construct easily accessible fluorogenic probes. Mutual orthogonality of the IEDDA reaction of 2-pyrones with SPAAC reactions of azides was also explored.

Key words IEDDA, bioorthogonal, 2-pyrone, fluorogenic probes, protein labeling

With its range of emerging reactions, bioorthogonal chemistry has revolutionized the field of chemical biology in the last two decades. ${ }^{1}$ Manipulation of biomolecules through these rapid, high yielding, biocompatible, and highly selective reactions has greatly facilitated our ultimate goal of understanding biological processes. Among the existing bioorthogonal reactions, the inverse-electron-demand Diels-Alder (IEDDA) reactions of tetrazines and strained cyclooctenes or cyclooctynes deserve special attention for its remarkable reaction kinetics and full biocompatibility. ${ }^{2}$ Moreover, the tetrazine moiety is able to quench the fluorescence of suitable fluorescent frames. This two-in-one feature of the tetrazine moiety was harnessed in the development of bioorthogonally applicable fluoro- genic probes. ${ }^{3}$ While the field of bioorthogonal chemistry and imaging probes have benefited greatly from tetrazines, the need for mutually orthogonal bioorthogonal reactions, for example in multi-color labeling schemes, called for the development of alternative bioorthogonal reactions. ${ }^{4}$ This includes development of novel dienes for IEDDA schemes with substantially different reactivities toward strained alkenes/alkynes. ${ }^{5 a, b}$ Such needs were addressed recently by the development of triazines that can also react with strained dienophiles in IEDDA reactions. ${ }^{5 c, d}$ Sydnones can also react with strained alkynes in thermal [3+2] cycloadditions and, similarly, they can render fluorescent cores fluorogenic. ${ }^{5 e}$ These are very important additions to the bioorthogonal toolbox, offering more options to develop mutually orthogonal bioorthogonal chemistries.5f,g IEDDA reactions of 2-pyrones have been known for quite a while 6 and even used to access bioorthogonal functions, such as in the synthesis of a reactive cyclooctyne; ${ }^{7}$ yet, to our knowledge, the use of 2-pyrones as bioorthogonally applicable dienes remained unexplored.

Our research group has been heavily involved ${ }^{8}$ in the design and synthesis of bioorthogonally applicable fluorogenic probes for protein labeling purposes and, in this context, the 2-pyrone moiety seems a particularly useful platform. We reasoned that 2-pyrones form a benzene ring with suitable alkynes via an IEDDA-retroDA reaction sequence (Scheme 1), which, upon careful design, would directly result in scaffolds with extended conjugation, giving rise to dramatic changes in spectroscopic properties. In line with the above discussed need for surrogate bioorthogonal functions, and to establish the viability of our hypothesis regarding the fluorogenic probe design potential of 2-py- 
rones, we set forth a study aiming at exploring the applicability of the 2-pyrone scaffold from these two aspects. Literature examples describe related reactions of 2-pyrones with electron-deficient alkynes that required long reaction times at higher temperatures; ${ }^{9}$ however, no studies under physiological conditions are reported. Therefore, we first set up a pilot experiment using commercially available methyl coumalate (1) with strained cyclooctyne BCN (Scheme 1) in aqueous solution at room temperature. We chose $\mathrm{BCN}$ as suitable dienophile because it produces an aromatic system (i.e., a substituted benzene ring) upon IEDDA reaction. Although more reactive trans-cyclooctenes could also be considered as complementary bioorthogonal platforms, their reaction would yield a cyclohexadiene. Since our goal is to fabricate fluorogenic systems taking advantage of the possible 2-in-1 feature of the pyrone scaffold, we foresaw that generation of a fully aromatic system would profoundly affect the spectroscopic characteristics of heterocycles.

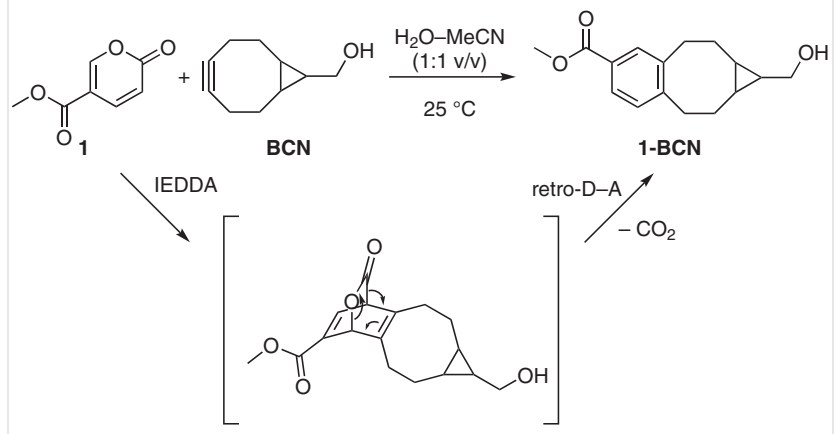

Scheme 1 Reaction of methyl coumalate (1) with BCN

To our delight, the overnight reaction of $\mathbf{1}$ and BCN resulted in the desired 1-BCN product in 90\% yield following chromatography. Inspired by this finding, we moved onto our ultimate goal; namely, to explore the feasibility of using the pyrone moiety in the fabrication of bioorthogonally applicable fluorogenic probes. To this end, we designed and synthesized a set of probes 2-6 furnished with a 2-pyrone moiety. The probes were designed in a way that in the product of the reaction with BCN the benzene ring becomes directly attached to a conjugated system, giving rise to $\pi$-extended structures (Scheme 2).

As stated above, we anticipated that the electronic differences between the pyrone and the benzene ring would dramatically change the photophysical properties of the probes, resulting in highly fluorogenic probes. For synthetic considerations, 4-hydroxy-6-methyl-pyrone (7) was chosen as a readily available starting material, which offers a conjugation site via its hydroxyl group. We believed that crosscoupling reactions of pseudohalogenated pyrones would allow a versatile approach for the synthesis of a wide variety of 2-pyrone derivatized scaffolds. ${ }^{10}$ Therefore, 7 was converted into its triflate derivative $\mathbf{8},{ }^{10 a}$ through treatment

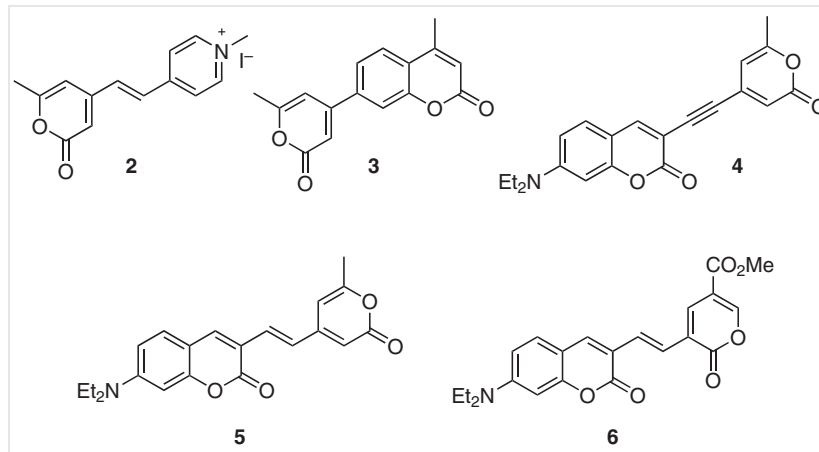

Scheme 2 Target bioorthogonal probes 2-6

with $\mathrm{PhNTf}_{2}$. After optimizing the reaction conditions, 8 could be prepared in good yields on the multi-gram scale and served as a common building block for further probes. First, 8 was coupled to 4 -vinylpyridine in a Heck reaction to access $\mathbf{9}$, which was $\mathrm{N}$-alkylated with methyl iodide to yield probe $\mathbf{2}$ (Scheme 3 ).
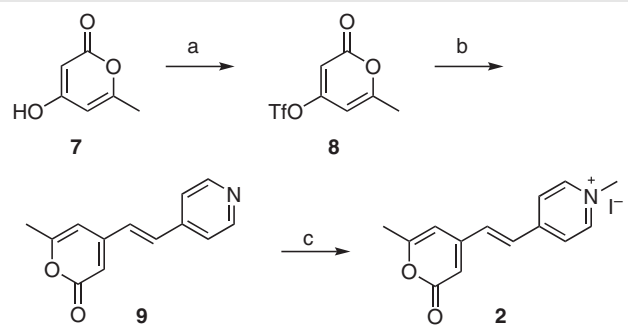

Scheme 3 Synthesis of probe 2. Reagents and conditions: (a) $\mathrm{PhNTf}_{2}$, $\mathrm{NEt}_{3}, \mathrm{DCM}, 40^{\circ} \mathrm{C}, 1 \mathrm{~h}, 88 \%$; (b) 4 -vinylpyridine, $\mathrm{Pd}_{2}(\mathrm{dba})_{3}$, QPhos, $\mathrm{Cy}_{2} \mathrm{NMe}, \mathrm{DMF}, 100^{\circ} \mathrm{C}, \mathrm{N}_{2}, 1 \mathrm{~h}, \mathrm{MW}, 50 \%$; (c) Mel, MeCN, $60^{\circ} \mathrm{C}, 1 \mathrm{~h}$, $20 \%$.

Next, 4-methyl-7-hydroxycoumarin (10) was converted into its pinacol boronic ester counterpart $\mathbf{1 2}^{11}$ in two steps. This was further reacted with $\mathbf{8}$ in a Suzuki cross-coupling reaction to result in target probe $\mathbf{3}$ (Scheme 4).

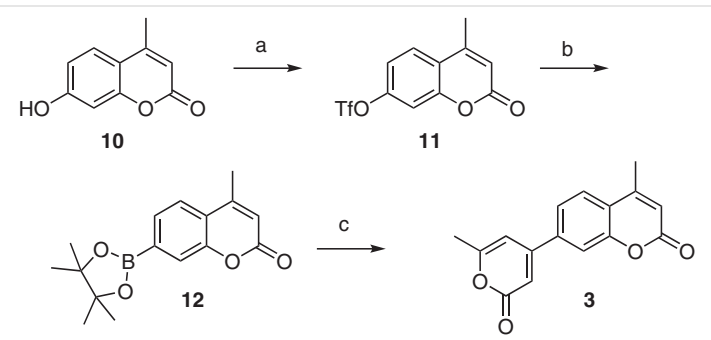

Scheme 4 Synthesis of probe 3. Reagents and conditions: (a) $\mathrm{PhNTf}_{2}$, $\mathrm{NEt}_{3}, \mathrm{DCM}, 40^{\circ} \mathrm{C}, 1 \mathrm{~h}, 85 \%$; (b) $\mathrm{B}_{2} \mathrm{Pin}_{2}, \mathrm{KOAc}, \mathrm{Pd}(\mathrm{dppf}) \mathrm{Cl}_{2}$, dioxane, $\mathrm{N}_{2}$, $100{ }^{\circ} \mathrm{C}, 2 \mathrm{~h}, 90 \%$; (c) 8, Pd(dppf) $\mathrm{Cl}_{2}, \mathrm{KOAc}, 1,4$-dioxane, $\mathrm{N}_{2}, 100{ }^{\circ} \mathrm{C}, 2 \mathrm{~h}$, $81 \%$.

To further extend the conjugated system, 7-diethylaminocoumarin (13) was prepared according to reported procedures. ${ }^{12}$ Site-selective bromination was effected with 
$\mathrm{N}$-bromosuccinimide (NBS) to yield 3-bromo derivative $\mathbf{1 4}$, which was subjected to a Sonogashira cross-coupling with TMS-acetylene to deliver 15. Removal of the TMS group gave 16, ${ }^{13}$ which was immediately used in a second Sonogashira coupling reaction with pyrone triflate $\mathbf{8}$, to give acetylene-linked probe 4 in excellent yield (Scheme 5).<smiles></smiles>

13

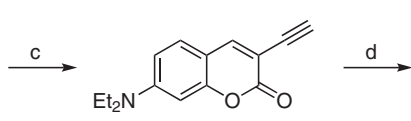

16<smiles></smiles>

Scheme 5 Synthesis of probe 4. Reagents and conditions: (a) NBS, $\mathrm{NH}_{4} \mathrm{OAC}, \mathrm{MeCN}, 25^{\circ} \mathrm{C}, 2 \mathrm{~h}$, dark, 30\%; (b) TMS-acetylene, $\mathrm{Pd}\left(\mathrm{PPh}_{3}\right)_{2} \mathrm{Cl}_{2}$, Cul, EDIPA, DMF, $\mathrm{N}_{2}, 45^{\circ} \mathrm{C}, 1 \mathrm{~h}, 91 \%$; (c) $1 \mathrm{M} \mathrm{TBAF}$ in THF, $25^{\circ} \mathrm{C}, 2 \mathrm{~h}$, 26\%; (d) 8, $\mathrm{Pd}\left(\mathrm{PPh}_{3}\right)_{2} \mathrm{Cl}_{2}$, Cul, EDIPA, MeCN, $\mathrm{N}_{2}, 45^{\circ} \mathrm{C}, 1 \mathrm{~h}$, quant.

To access vinylene extended probe $\mathbf{5}$, intermediate $\mathbf{1 8}$ was synthesized through a Vilsmeier-Haack formylation, ${ }^{12}$ Wittig reaction sequence, via 17. Finally, the pyrone ring was installed in a Heck reaction to yield $\mathbf{5}$ (Scheme 6).

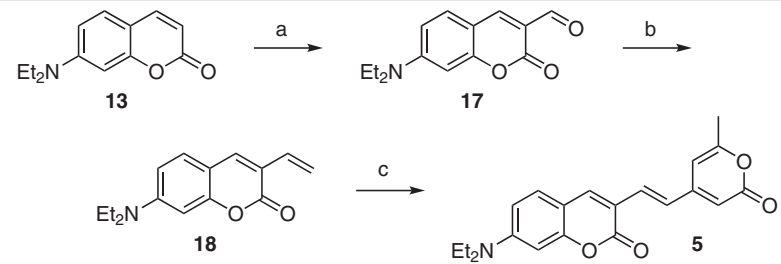

Scheme 6 Synthesis of probe 5. Reagents and conditions: (a) $\mathrm{POCl}_{3}$, DMF, $\mathrm{N}_{2}, 0^{\circ} \mathrm{C} / 30 \mathrm{~min}, 60^{\circ} \mathrm{C} / 16 \mathrm{~h}, 54 \%$; (b) i. $\mathrm{Ph}_{3} \mathrm{P}^{+} \mathrm{Me} \mathrm{Br}-$, $n$-BuLi/hexane, THF, $\mathrm{N}_{2}, 0{ }^{\circ} \mathrm{C}, 20 \mathrm{~min}$; ii. 17, THF, $25^{\circ} \mathrm{C}, 18 \mathrm{~h}, 47 \%$; (c) 8, $\mathrm{Pd}_{2}(\mathrm{dba})_{3}$, QPhos, $\mathrm{Cy}_{2} \mathrm{NMe}, \mathrm{DMF}, 100^{\circ} \mathrm{C}, \mathrm{N}_{2}, 1 \mathrm{~h}, \mathrm{MW}, 32 \%$.

To study the effects of different connectivity of the pyrone ring and to be able to install an electron-withdrawing group, which facilitates IEDDA reaction, we also prepared bromo-pyrone 19. ${ }^{14}$ Vinyl coumarin 18 was then allowed to react with 19 to yield probe $\mathbf{6}$ in good yield (Scheme 7).

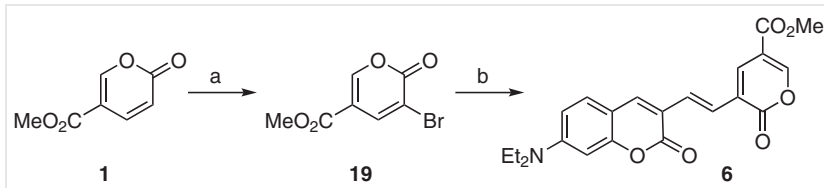

Scheme 7 Synthesis of probe 6 . Reagents and conditions: (a) $\mathrm{PBPB}, \mathrm{AcOH}$, $100{ }^{\circ} \mathrm{C}, 12 \mathrm{~h}, 41 \%$; (b) $18, \mathrm{Pd}_{2}(\mathrm{dba})_{3}$, QPhos, $\mathrm{Cy}_{2} \mathrm{NMe}, \mathrm{DMF}, 100^{\circ} \mathrm{C}, \mathrm{N}_{2}$, $1 \mathrm{~h}, \mathrm{MW}, 85 \%$.

With the desired molecules in hand, we tested their reactions with BCN and monitored the changes in their fluorescence spectra. Results showed that all compounds react- ed with $\mathrm{BCN}$; however, the change in the fluorescence properties varied considerably (Table 1 and see the Supporting Information for spectra). Compound $\mathbf{2}$ and its reaction product with BCN (2-BCN) both showed large Stokes shifts; however, the intensity of the fluorescence increased by only about threefold upon reaction. Probes $\mathbf{3}$ and 3-BCN showed similar absorption and emission properties, with somewhat larger (13-fold) increase in fluorescence. These latter two probes, however, required UV excitation, which is not ideal for biological applications. Probe $\mathbf{4}$, on the other hand, showed significantly redshifted excitation and emission maxima, both of which were slightly blueshifted upon reaction with BCN. Notably, however, this reaction was accompanied by a huge increase in the intensity of fluorescence (over 100 -fold). Reaction of probe $\mathbf{5}$ with $\mathrm{BCN}$ resulted in decreased fluorescence intensity and the disappearance of the originally large Stokes shift. Changing the substitution pattern of the 2-pyrone frame and introducing an electronwithdrawing group onto it (6) resulted in a hypsochromic shift compared to $\mathbf{5}$, and only a slight increase in fluorescence was observed upon reaction. These results indicate that the position and the nature of the linkage between the 2-pyrone and the fluorescent frame should be carefully considered during the design process.

Table 1 Excitation and Emission Maxima ${ }^{\mathrm{a}}$ of the New Fluorescent Dyes and the Change in Fluorescence Intensity upon Reaction of BCN

\begin{tabular}{|c|c|c|c|}
\hline Compound & $\lambda_{\max }(\mathrm{ex})(\mathrm{nm})$ & $\lambda_{\max }(\mathrm{em})(\mathrm{nm})$ & Change in fluorescence \\
\hline $\begin{array}{l}2 \\
2-B C N\end{array}$ & $\begin{array}{l}360 \\
365\end{array}$ & $\begin{array}{l}491 \\
484\end{array}$ & slight increase (ca. $3.3 \times$ ) \\
\hline $\begin{array}{l}3 \\
3-B C N\end{array}$ & $\begin{array}{l}335 \\
334\end{array}$ & $\begin{array}{l}429 \\
424\end{array}$ & increase (ca. 12-13×) \\
\hline $\begin{array}{l}4 \\
4-B C N\end{array}$ & $\begin{array}{l}465 \\
426\end{array}$ & $\begin{array}{l}536 \\
487\end{array}$ & huge increase $(>100 \times)$ \\
\hline $\begin{array}{l}5 \\
5-B C N\end{array}$ & $\begin{array}{l}469 \\
538\end{array}$ & $\begin{array}{l}593 \\
565\end{array}$ & decrease \\
\hline $\begin{array}{l}6 \\
6-B C N\end{array}$ & $\begin{array}{l}407 \\
422\end{array}$ & $\begin{array}{l}490 \\
528\end{array}$ & slight increase (ca. $2.5 \times$ ) \\
\hline
\end{tabular}

Based on these findings, we chose $\mathbf{4}$ for further experiments. First, we quantified its reaction speed with $\mathrm{BCN}$ and found the second-order rate constant to be $k_{2}=0.095 \mathrm{M}^{-1} \mathrm{~s}^{-1}$, which is in the same order of magnitude as the well-established strain-promoted cycloaddition reactions of azides and strained alkynes (e.g., DIFO and BCN have a $k_{2}$ of 0.076 and 0.14 , respectively). ${ }^{15}$ We also measured the molar absorption coefficients, fluorescence quantum yields, and the fluorescence enhancement (Table 2).

To test whether the pyrone-derivatized bioorthogonally applicable fluorogenic probe $\mathbf{4}$ is suitable for protein labeling, we first functionalized a human serum protein, Transferrin (TF, $76 \mathrm{kDa}$ ) with BCN using BCN-NHS. Following removal of unreacted reagents, probe $\mathbf{4}$ was added to the 
Table 2 Spectral Properties ${ }^{\mathrm{a}}(\varepsilon$ and $\varphi$ values) of $\mathbf{4}$ and $\mathbf{4 - B C N}$ and the Calculated Fluorescence Enhancement upon Reaction with BCN

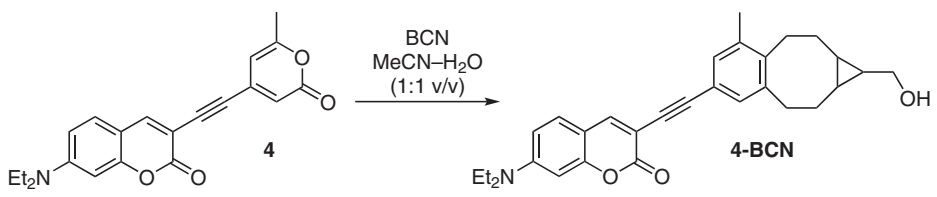

\begin{tabular}{lccc}
\hline 4 & & $4-\mathrm{BCN}$ & $\varphi^{\mathrm{b}}$ \\
$\varepsilon_{465 \mathrm{~nm}}\left(\mathrm{M}^{-1} \mathrm{Cm}^{-1}\right)$ & $\varphi^{\mathrm{b}}$ & $\varepsilon_{426 \mathrm{~nm}}\left(\mathrm{M}^{-1} \mathrm{~cm}^{-1}\right)$ & 1.0 \\
\hline 52730 & 0.009 & 33150 & $111 \times$ \\
Fluorescence enhancement $\left(\varphi_{4-\mathrm{BCN}} / \varphi_{4}\right):$ & & & $11 \times$ \\
\hline
\end{tabular}

a Measurement conditions: $50 \% \mathrm{MeCN}$ in $\mathrm{H}_{2} \mathrm{O}, 25^{\circ} \mathrm{C}$.

${ }^{\mathrm{b}}$ Using coumarin-153 in $\mathrm{EtOH}(\varphi=0.544)$ as reference standard. ${ }^{16}$

samples at different concentrations (i.e., 125,250 or 500 $\mu \mathrm{M})$. Following 24 hour incubation, the reaction mixtures were worked up, then the samples were subjected to an SDS-polyacrylamide gel, and in-gel fluorescence detection (Figure 1). Fluorescent Transferrin bands occurred in the lanes only where Transferrin was co-incubated both with NHS-BCN and 4. As expected, fluorescence intensity was proportional to the concentration of the probe added. These results indicated that the fluorogenic probe 4 indeed reacted specifically with transferrin-conjugated $\mathrm{BCN}$, in a concentration-dependent manner. As control experiments we mixed probe 4 with Transferrin that was not treated with $\mathrm{BCN}$ previously. Only a very low fluorescent signal was observed, indicating that fluorogenic $\mathbf{4}$ in its quenched (i.e., 2pyrone) form does not contribute to background fluorescence even when it is adhered non-specifically to the protein by adsorption. We have also studied the labeling scheme of further proteins including $\beta$-lactoglobulin $B, \alpha 1-$ acid glycoprotein, myoglobin and a trypsin inhibitor, each of which showed similar results to transferrin labeling (see the Supporting Information). To explore the labeling efficacy, we have also labeled a BCN-tagged 17-mer oligonucleotide and a BCN-tagged cyclic peptide, phalloidin. The reactions were followed either by capillary electrophoresis or by LC-MS. The labeling reactions were accomplished either in 50\% DMSO-water (oligonucleotide) or in methanol (phalloidin). Mass spectrometry proved the formation of the expected products; however, the conversion rates were very different, i.e., $33 \%$ vs. $100 \%$ for the aqueous solution and methanol, respectively, which is attributed to the limited solubility of compound $\mathbf{4}$ (see the Supporting Information).

The stability of compound $\mathbf{4}$ was assessed in the presence of excess amounts of GSH (1-10 mM). LC-MS analysis of the samples indicated no substantial change of the pyrone in the presence of up to $5 \mathrm{mM} \mathrm{GSH}$ after 24 hours. Higher amounts of GSH (10 mM), however, led to ca. $20 \%$ decomposition of $\mathbf{4}$ after 24 hours and MS indicated the

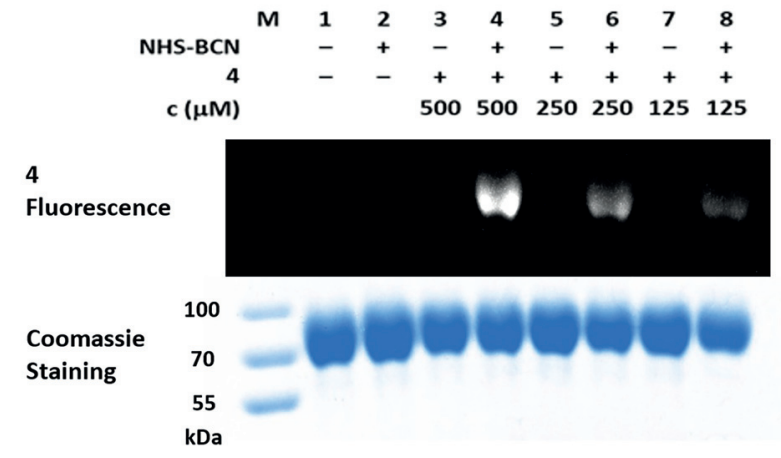

Figure 1 In-gel SDS PAGE representation of the ability of the fluorogenic coumarin-pyrone derivative $\mathbf{4}$ to label the serum protein Transferrin (TF) modified with NHS-BCN. Top image is the fluorescent channel detected using 460-490 nm excitation and emission detection with a $532 / 28 \mathrm{~nm}$ band pass filter. Coomassie staining to indicate equal protein loading is shown in the lower image. Molecular weights corresponding to the visible bands of the marker are indicated.

presence of a 4-GSH adduct. We also checked fluorescence spectra of these samples and, to our delight, found no change in the emission spectrum, indicating that the product is not fluorescent.

We also explored the mutual orthogonality of the 2-pyrone moiety in the presence of other bioorthogonal functions. We assumed that, similar to tetrazines, 2-pyrones are also inert towards sterically demanding dibenzocyclooctynes, such as DBCO. ${ }^{5 f}$ Preliminary studies confirmed that 4 indeed does not react with DBCO. We then combined excess amounts of DBCO and BCN and added 2-pyrone, bearing probe 4 , to this solution. Next, all the remaining BCN was consumed by adding a tetrazine bearing fluorogenic probe, PheCou, ${ }^{17 a}$ in excess. Finally, we added an azidebearing probe, CBRD. ${ }^{17 \mathrm{~b}}$ The reaction mixture was then analyzed by LC-MS. To our delight, only the three expected products could be detected; namely, 4-BCN, PheCou-BCN, and CBRD-DBCO (see the Supporting Information). 
In conclusion, we have explored the potential of the 2pyrone moiety in bioorthogonal reaction schemes in combination with strained alkyne, BCN. The inverse-electrondemand Diels-Alder reaction follows a moderate kinetics with second-order rate constant around $0.1 \mathrm{M}^{-1} \mathrm{~s}^{-1}$, which is similar to, for example, SPAAC reactions of azides with $\mathrm{BCN}$. We also prepared several 2-pyrone appended probes, one of which showed remarkable fluorescence increase upon IEDDA reaction with $\mathrm{BCN}$. We also demonstrated the applicability of our new 2-pyrone probe in protein labeling schemes in vitro with various $\mathrm{BCN}$-modified proteins. Sequential addition of $\mathbf{4}$, a tetrazine- and an azide-appending probe, to a mixture of $B C N$ and $D B C O$ revealed that the SPAAC reaction of azides and the IEDDA of 2-pyrones can be conducted orthogonally upon careful selection of reaction partners.

Since tetrazines are very hard to connect directly to fluorescent frames, as only a few examples are reported, ${ }^{3 \mathrm{~b}, 18}$ we believe that the finding that the 2-pyrone moiety allows several cross-coupling reactions (e.g., Heck, Suzuki, Sonogashira) giving rise to various 2-pyrone-appending profluorescent frames, further highlights the significance of this study. The pyrone moiety is stable, easy to handle, and, similar to the tetrazine function, can also participate in IEDDA reactions, which upon careful design, can result in fluorogenic probes. Upon reacting with alkynes, the formed aromatic moiety allows direct extension of conjugated systems. Furthermore, by adding the pyrone moiety to the bioorthogonal reaction tool-box, we envision that it can be applied to develop mutually orthogonal bioorthogonal reactions taking advantage of its substantially different reaction kinetics.

All starting materials were obtained from commercial suppliers (Sigma-Aldrich, Fluka, Merck, Alfa Aesar, Reanal, Molar Chemicals, Fluorochem) and used without further purification. $(1 R, 8 S, 9 S)$-Bicyclo[6.1.0]non-4-yn-9-ylmethanol (BCN) and the corresponding succynimidyl carbonate (BCN-NHS) was obtained from Sigma. Analytical thin-layer chromatography (TLC) was performed on silica gel 60 F254 precoated aluminum TLC plates from Merck. Flash column chromatography was performed with a Teledyne Isco CombiFlash ${ }^{\circledR} \mathrm{Rf}^{+}$automated flash chromatographer with silica gel $(25-40 \mu \mathrm{m})$ from Zeochem. Microwave experiments were carried out with an AntonPaar (Graz, Austria) Monowave 300 microwave reactor (maximum power $850 \mathrm{~W}$ ). NMR spectra were recorded with a Varian Inova $500 \mathrm{MHz}$ spectrometer. Chemical shifts $(\delta)$ are given in parts per million (ppm) using solvent signals or TMS as the reference. Coupling constants $(J)$ are reported in hertz $(\mathrm{Hz})$. Analytical RP-HPLC-UV/Vis-MS measurements were conducted with a Shimadzu LCMS-2020 instrument applying a Gemini C18 column $(100 \times 2.00 \mathrm{~mm}$ I.D. $)$ in which the stationary phase was $5 \mu \mathrm{m}$ silica with a pore size of $110 \AA$. The chromatograms were detected with UV/Vis diode array $(190-800 \mathrm{~nm})$ and ESI-MS detectors. Linear gradient elution (0 min 0\% B; 2.0 min $100 \%$ B; 3.5 min $100 \%$ B; 4.5 min $0 \%$ B; 5.0 min $0 \%$ B) with eluents A ( $2 \%$ $\mathrm{HCOOH}, 5 \% \mathrm{MeCN}$, and $\left.93 \% \mathrm{H}_{2} \mathrm{O}\right)$ and $\mathrm{B}(2 \% \mathrm{HCOOH}, 80 \% \mathrm{MeCN}$, and $18 \% \mathrm{H}_{2} \mathrm{O}$ ) was used at a flow rate of $1.0 \mathrm{~mL} \mathrm{~min}^{-1}$ at $30^{\circ} \mathrm{C}$. The samples were dissolved in $\mathrm{MeCN}-\mathrm{H}_{2} \mathrm{O}$ mixture. Spectroscopic measurements were performed with a Jasco FP 8300 spectrofluorometer. Quartz cuvettes with path length of $1 \mathrm{~cm}$ were used. The exact masses were determined with an Agilent 6230 time-of-flight mass spectrometer.

Methyl 1-(Hydroxymethyl)-1a,2,3,8,9,9a-hexahydro-1H-benzo[a]cyclopropa[e][8]annulene-5-carboxylate (1-BCN)

In a round-bottom flask, methyl coumalate $(\mathbf{1} ; 5.0 \mathrm{mg}, 0.033 \mathrm{mmol}, 1$ equiv) was dissolved in $50 \% \mathrm{MeCN}-\mathrm{H}_{2} \mathrm{O}(1 \mathrm{~mL})$ and $\mathrm{BCN}(15 \mathrm{mg}, 0.10$ mmol, 3 equiv) was added. The reaction mixture was stirred at $25{ }^{\circ} \mathrm{C}$ for 18 hours, then concentrated in vacuo on a rotary evaporator. The crude product was purified by flash column chromatography $(0 \rightarrow 60 \%$, EtOAc-hexane) to give the desired product.

Yield: $7.6 \mathrm{mg}$ (90\%); white solid.

${ }^{1} \mathrm{H}$ NMR $\left(\mathrm{CDCl}_{3}, 500 \mathrm{MHz}\right): \delta=7.80-7.75(\mathrm{~m}, 2 \mathrm{H}), 7.16(\mathrm{~d}, J=8.4 \mathrm{~Hz}, 1$ H), $3.89(\mathrm{~s}, 3 \mathrm{H}), 3.70$ (dd, $J=7.8,1.3 \mathrm{~Hz}, 2 \mathrm{H}), 3.06-2.95(\mathrm{~m}, 2 \mathrm{H}), 2.81$ (m, $2 \mathrm{H}), 2.31-2.20(\mathrm{~m}, 2 \mathrm{H}), 1.49(\mathrm{~m}, 2 \mathrm{H}), 1.13-1.02(\mathrm{~m}, 1 \mathrm{H}), 0.91$ $(\mathrm{m}, 2 \mathrm{H})$

${ }^{13} \mathrm{C}$ NMR $\left(\mathrm{CDCl}_{3}, 126 \mathrm{MHz}\right): \delta=167.5,147.7,142.2,131.3,130.4$, $128.0,127.5,59.9,52.0,33.6,33.4,24.54,24.53,22.1,19.4$.

LC-MS (ESI): $m / z=261\left(\mathrm{C}_{16} \mathrm{H}_{21} \mathrm{O}_{3}\right)[\mathrm{M}+\mathrm{H}]^{+}$.

\section{6-Methyl-2-oxo-2H-pyran-4-yl Trifluoromethanesulfonate (8) ${ }^{10 \mathrm{a}}$}

4-Hydroxy-6-methyl-pyrone (7; $631 \mathrm{mg}, 1.20 \mathrm{mmol}, 1$ equiv) and $N$ phenyl-bis(trifluoromethanesulfonimide) $(1.97 \mathrm{~g}, 1.32 \mathrm{mmol}, 1.1$ equiv) were dissolved in DCM ( $40 \mathrm{~mL}$, stabilized with amylene), then triethylamine ( $1.00 \mathrm{~mL}, 1.80 \mathrm{mmol}, 1.5$ equiv) was added, and the reaction mixture was stirred at $40{ }^{\circ} \mathrm{C}$ for $1 \mathrm{~h}$. After cooling to r.t., it was diluted with EtOAc $(200 \mathrm{~mL})$, washed with sat. $\mathrm{NaHCO}_{3}(3 \times 100 \mathrm{~mL})$ and dried over $\mathrm{MgSO}_{4}$. After filtration and evaporation, the crude product was purified by flash column chromatography (hexane-EtOAc, $10: 1 \mathrm{v} / \mathrm{v}$ ) to give the desired product.

Yield: $1.14 \mathrm{~g}(88 \%)$; colorless oil.

Repeating the same procedure with $\mathbf{7}$ (3.00 g) under similar conditions gave 8 ( $5.29 \mathrm{~g}, 86 \%)$ as a pale-yellow oil, which solidified in the freezer.

It is important to note, that $\mathbf{8}$ slowly decomposed in the fridge, but was stable at $-20^{\circ} \mathrm{C}$.

$R_{f} 0.76$ (hexane-EtOAc, $1: 1 \mathrm{v} / \mathrm{v}$ ).

IR (neat): 3104, 1743, 1646, 1575, 1429, 1318, 1206, 1134, 1109, 961, $803 \mathrm{~cm}^{-1}$.

${ }^{1} \mathrm{H} \mathrm{NMR}\left(\mathrm{CDCl}_{3}, 500 \mathrm{MHz}\right): \delta=6.10(\mathrm{~s}, 1 \mathrm{H}), 6.05(\mathrm{~s}, 1 \mathrm{H}), 2.31(\mathrm{~s}, 3 \mathrm{H})$. ${ }^{13} \mathrm{C} \mathrm{NMR}\left(\mathrm{CDCl}_{3}, 126 \mathrm{MHz}\right): \delta=165.7,161.7,161.1,120.6,102.5,99.7$, 20.4 .

HRMS (ESI): $m / z[M+H]^{+}$calcd for $\mathrm{C}_{7} \mathrm{H}_{6} \mathrm{~F}_{3} \mathrm{O}_{5} \mathrm{~S}: 258.9888$; found: 258.9893.

\section{(E)-6-Methyl-4-(2-(pyridin-4-yl)vinyl)pyrone (9)}

In a microwave pressure tube with a magnetic stir bar, 4-vinylpyridine (122 mg, $1.16 \mathrm{mmol}, 3$ equiv) and 8 (100 mg, $0.39 \mathrm{mmol}, 1$ equiv) were dissolved in abs. DMF ( $4 \mathrm{~mL}$ ) under $\mathrm{N}_{2} \cdot N, N$-Dicyclohexylmethylamine ( $410 \mu \mathrm{L}, 1.94 \mathrm{mmol}, 5$ equiv), QPhos ( $14 \mathrm{mg}, 0.02 \mathrm{mmol}$, 0.05 equiv) and $\mathrm{Pd}_{2}(\mathrm{dba})_{3}(17 \mathrm{mg}, 0.02 \mathrm{mmol}, 0.05$ equiv) were added and the reaction mixture was heated in a microwave reactor at $100{ }^{\circ} \mathrm{C}$ for 1 hour. The solvent was evaporated in vacuo and the crude product was purified by flash chromatography twice (first with DCM$\mathrm{MeOH}, 20: 1$, then hexane-EtOAc, 1:1 v/v eluent) to give the product. Yield: $42 \mathrm{mg}$ (50\%); sticky white solid; $R_{f} 0.31$ (DCM-MeOH, 20:1 v/v). 
IR (neat): 2925, 2852, 2781, 1737, 1594, 1448, 1261, 1199, 1049, 890 $\mathrm{cm}^{-1}$.

${ }^{1} \mathrm{H}$ NMR $\left(\mathrm{CD}_{3} \mathrm{CN}, 500 \mathrm{MHz}\right): \delta=8.59(\mathrm{~d}, J=6.1 \mathrm{~Hz}, 2 \mathrm{H}), 7.50(\mathrm{~d}, J=6.1$ $\mathrm{Hz}, 2 \mathrm{H}), 7.31$ (d, $J=16.4 \mathrm{~Hz}, 1 \mathrm{H}), 7.17$ (d, $J=16.4 \mathrm{~Hz}, 1 \mathrm{H}), 6.47$ (s, 1 $\mathrm{H}), 6.16(\mathrm{~s}, 1 \mathrm{H}), 2.25(\mathrm{~s}, 3 \mathrm{H})$.

${ }^{13} \mathrm{C}$ NMR $\left(\mathrm{CD}_{3} \mathrm{CN}, 126 \mathrm{MHz}\right): \delta=163.13,153.34,152.25,151.05$, 144.28, 134.76, 130.08, 122.51, 111.42, 101.25, 20.12.

HRMS (ESI): $m / z[M+H]^{+}$calcd for $\mathrm{C}_{13} \mathrm{H}_{12} \mathrm{NO}_{2}: 214.0868$; found: 214.0865 .

\section{(E)-1-Methyl-4-(2-(6-methyl-2-oxo-2H-pyran-4-yl)vinyl)pyridin-} 1-ium Iodide (2)

Compound $\mathbf{9}$ ( $52 \mathrm{mg}, 0.24 \mathrm{mmol}, 1$ equiv) was dissolved in anhydrous acetonitrile $(4 \mathrm{~mL})$ in a pressure tube, then methyl iodide $(150 \mu \mathrm{L}$, $2.40 \mathrm{mmol}, 10$ equiv) was added and the vial was sealed. The reaction mixture was stirred at $60^{\circ} \mathrm{C}$ for $1 \mathrm{~h}$, then cooled to r.t. and the solvent was evaporated. The crude product was suspended in EtOAc, filtered, and washed with EtOAc to give the desired product, which required no further purification.

Yield: $18 \mathrm{mg}$ (20\%); yellow powder.

IR (neat): 3041, 3012, 1734, 1705, 1639, 1517, 1312, 1228, 984, 846 $\mathrm{cm}^{-1}$.

${ }^{1} \mathrm{H}$ NMR $\left(\mathrm{D}_{2} \mathrm{O} / \mathrm{CD}_{3} \mathrm{CN}, 500 \mathrm{MHz}\right): \delta=9.05(\mathrm{~s}, 2 \mathrm{H}), 8.49(\mathrm{~s}, 2 \mathrm{H}), 7.88(\mathrm{~s}$, $2 \mathrm{H}), 7.03$ (s, $1 \mathrm{H}), 6.77$ (s, $1 \mathrm{H}), 4.67(\mathrm{~s}, 3 \mathrm{H}), 2.68(\mathrm{~s}, 3 \mathrm{H})$.

${ }^{13} \mathrm{C} \operatorname{NMR}\left(\mathrm{D}_{2} \mathrm{O} / \mathrm{CD}_{3} \mathrm{CN}, 126 \mathrm{MHz}\right): \delta=165.1,162.6,150.9,150.6,144.5$, 134.6, 130.4, 124.6, 111.1, 100.9, 47.0, 18.5.

HRMS (ESI): $m / z$ [M] ${ }^{+}$calcd for $\mathrm{C}_{14} \mathrm{H}_{14} \mathrm{NO}_{2}$ : 228.1025; found: 228.1016.

\section{4-Methyl-coumarin-7-yl Trifluoromethanesulfonate (11) and 4- Methyl-7-(4,4,5,5-tetramethyl-1,3,2-dioxaborolan-2-yl)coumarin (12)}

Prepared according to reported procedures ${ }^{11}$ with slight modifications.

7-Hydroxy-4-methyl-coumarin (10; $176 \mathrm{mg}, 1.0 \mathrm{mmol}, 1$ equiv) and $\mathrm{N}$-phenyl-bis(trifluoromethanesulfonimide) (393 mg, $1.1 \mathrm{mmol}, 1.1$ equiv) were dissolved in DCM ( $20 \mathrm{~mL}$, stabilized with amylene), then triethylamine $(0.21 \mathrm{~mL}, 1.5 \mathrm{mmol}, 1.5$ equiv) was added and the reaction mixture was stirred at $40{ }^{\circ} \mathrm{C}$ for $1 \mathrm{~h}$. After cooling to r.t., it was diluted with EtOAc $(200 \mathrm{~mL})$, washed with sat. $\mathrm{NaHCO}_{3}(3 \times 100 \mathrm{~mL})$ and dried over $\mathrm{MgSO}_{4}$. After filtration and evaporation of the solvent, the crude product was purified by flash column chromatography $(0 \rightarrow 50 \%$, EtOAc-hexane) to give $\mathbf{1 1}$.

Yield: $262 \mathrm{mg}$ (85\%); white crystalline solid; $R_{f} 0.63$ (hexane-EtOAc, $1: 1 \mathrm{v} / \mathrm{v})$.

${ }^{1} \mathrm{H} \mathrm{NMR}\left(\mathrm{CDCl}_{3}, 500 \mathrm{MHz}\right): \delta=(\mathrm{d}, J=8.8 \mathrm{~Hz}, 1 \mathrm{H}), 7.29(\mathrm{~d}, J=2.4 \mathrm{~Hz}, 1$ H), $7.24(\mathrm{dd}, J=8.8,2.4 \mathrm{~Hz}, 1 \mathrm{H}), 6.36(\mathrm{~d}, J=1.2 \mathrm{~Hz}, 1 \mathrm{H}), 2.46$ (d, $J=1.2$ $\mathrm{Hz}, 3 \mathrm{H})$.

LC-MS (ESI): $m / z=309\left(\mathrm{C}_{11} \mathrm{H}_{8} \mathrm{~F}_{3} \mathrm{O}_{5} \mathrm{~S}\right)[\mathrm{M}+\mathrm{H}]^{+}$.

Then compound 11 (202 mg, $0.66 \mathrm{mmol}, 1$ equiv), bis(pinacolato)diboron (200 mg, $0.79 \mathrm{mmol}, 1.2$ equiv) and anhydrous KOAc (159 mg, $1.62 \mathrm{mmol}$, 3.6 equiv) were dissolved in abs. 1,4-dioxane ( $6 \mathrm{~mL})$ under $\mathrm{N}_{2}$ atmosphere. $\mathrm{Pd}(\mathrm{dppf}) \mathrm{Cl}_{2}$ ( $30 \mathrm{mg}, 0.04 \mathrm{mmol}, 0.06$ equiv) was added and the reaction mixture was stirred at $100{ }^{\circ} \mathrm{C}$ for 2 hours. After cooling to r.t., water $(100 \mathrm{~mL})$ was added and the mixture was extracted with EtOAc $(3 \times 75 \mathrm{~mL})$. The combined organic phases was washed with brine $(100 \mathrm{~mL})$ and dried over $\mathrm{MgSO}_{4}$. The crude prod- uct was purified by flash column chromatography $(0 \rightarrow 5 \%$, DCM$\mathrm{MeOH}$ ) to give the product as a mixture of the pinacolatoboron and the free boronic acid derivatives, which was used in the next step.

Yield: $133 \mathrm{mg}$ (90\%); off-white solid.

IR (neat): 2979, 1730, 1622, 1508, 1338, 1280, 1125, $850 \mathrm{~cm}^{-1}$.

LC-MS (ESI): $m / z=287\left(\mathrm{C}_{16} \mathrm{H}_{20} \mathrm{BO}_{4}\right)[\mathrm{M}+\mathrm{H}]^{+}$for 12 and $m / z=203$ $\left(\mathrm{C}_{10} \mathrm{H}_{8} \mathrm{BO}_{4}\right)[\mathrm{M}-\mathrm{H}]^{-}$for the free boronic acid derivative.

\section{4-Methyl-7-(6-methyl-2-oxo-2H-pyran-4-yl)coumarin (3)}

Compound 12 (128 mg, $0.45 \mathrm{mmol}, 1$ equiv), 8 (115 mg, $0.45 \mathrm{mmol}, 1$ equiv), and anhydrous KOAc ( $232 \mathrm{mg}, 2.36 \mathrm{mmol}, 3.6$ equiv) were dissolved in abs. 1,4-dioxane (6 mL). Pd(dppf) $\mathrm{Cl}_{2}(19.8 \mathrm{mg}, 0.027 \mathrm{mmol}$, 0.06 equiv) was added and the reaction mixture was stirred at $100{ }^{\circ} \mathrm{C}$ for 2 hours. After cooling to r.t., water $(100 \mathrm{~mL})$ was added and the mixture was extracted with EtOAc $(3 \times 75 \mathrm{~mL})$. The combined organic phases was washed with brine $(100 \mathrm{~mL})$ and dried over $\mathrm{MgSO}_{4}$. The crude product was purified by flash column chromatography $(0 \rightarrow 5 \%$, $\mathrm{DCM}-\mathrm{MeOH}$ ) to give the desired product.

Yield: $98 \mathrm{mg}$ (81\%); pale-yellow solid; $R_{f} 0.26$ (hexane-EtOAc, $1: 1 \mathrm{v} / \mathrm{v}$ ). IR (neat): 3051, 2921, 1707, 1634, 1323, 1026, $871 \mathrm{~cm}^{-1}$.

${ }^{1} \mathrm{H}$ NMR $\left(\mathrm{CDCl}_{3}, 500 \mathrm{MHz}\right): \delta=7.70(\mathrm{~d}, J=8.0 \mathrm{~Hz}, 1 \mathrm{H}), 7.52-7.48(\mathrm{~m}, 2$ $\mathrm{H}), 6.40(\mathrm{~s}, 1 \mathrm{H}), 6.37(\mathrm{~d}, J=1.0 \mathrm{~Hz}, 1 \mathrm{H}), 6.28(\mathrm{~s}, 1 \mathrm{H}), 2.48(\mathrm{~d}, J=1.1$ $\mathrm{Hz}, 3 \mathrm{H}), 2.35$ (s, $3 \mathrm{H})$.

${ }^{13} \mathrm{C}$ NMR $\left(\mathrm{CDCl}_{3}, 126 \mathrm{MHz}\right): \delta=163.7,162.1,153.6,151.6,150.6$, 125.6, 122.5, 121.6, 116.5, 115.3, 110.7, 109.5, 103.0, 101.5, 20.4, 18.7. HRMS (ESI): $m / z[M+H]^{+}$calcd for $\mathrm{C}_{16} \mathrm{H}_{13} \mathrm{O}_{4}$ : 269.0814; found: 269.0807.

3-Bromo-7-(diethylamino)-coumarin (14), 7-(Diethylamino)-3((trimethylsilyl)ethynyl)-coumarin (15) and 7-(Diethylamino)-3ethynyl-coumarin (16)

Prepared according to reported procedures ${ }^{13}$ with slight modifications.

In a round-bottom flask 7-(diethylamino)-coumarin (13; $2.60 \mathrm{~g}, 12.0$ mmol, 1 equiv) and $\mathrm{NH}_{4} \mathrm{OAc}(92 \mathrm{mg}, 1.2 \mathrm{mmol}, 0.1$ equiv) were dissolved in acetonitrile $(250 \mathrm{~mL})$ and $N$-bromosuccinimide ( $2.60 \mathrm{~g}, 14.3$ mmol, 1.2 equiv) was added while stirring. The reaction mixture was stirred at r.t. for 2 hours in the dark (covered with aluminum foil), then concentrated onto silica. The crude product was partially purified by column chromatography (hexane-EtOAc, 4:1 v/v), then recrystallized from acetonitrile and washed with cold $\mathrm{Et}_{2} \mathrm{O}$ to give 14.

Yield: $1.03 \mathrm{~g}$ (30\%); light-brown solid; $R_{f} 0.76$ (hexane-EtOAc, $1: 1$ $\mathrm{v} / \mathrm{v}$ ); $R_{f} 0.50$ (hexane-EtOAc, 3:1 v/v).

LC-MS (ESI): $m / z=296$ and $298\left(\mathrm{C}_{13} \mathrm{H}_{15} \mathrm{BrNO}_{2}\right)[\mathrm{M}+\mathrm{H}]^{+}$.

Compound 14 (500 mg, $1.7 \mathrm{mmol}, 1$ equiv), Cul ( $74 \mathrm{mg}, 0.39 \mathrm{mmol}$, 0.2 equiv), and $\mathrm{Pd}\left(\mathrm{PPh}_{3}\right)_{2} \mathrm{Cl}_{2}$ (119 $\mathrm{mg}, 0.17 \mathrm{mmol}, 0.1$ equiv) was mixed in a round-bottom flask under $\mathrm{N}_{2}$ atmosphere. Then anhydrous DMF (15 mL), EDIPA (1.2 mL, $6.8 \mathrm{mmol}, 4$ equiv) and trimethylsilylacetylene $(0.70 \mathrm{~mL}, 5.1 \mathrm{mmol}, 3$ equiv) were added. The reaction mixture was stirred at $45^{\circ} \mathrm{C}$ for $1 \mathrm{~h}$, then water $(150 \mathrm{~mL})$ was added and the mixture was extracted with DCM $(3 \times 100 \mathrm{~mL})$. The combined organic phases was washed with sat. EDTA $(100 \mathrm{~mL})$, brine $(100 \mathrm{~mL})$ and dried over $\mathrm{MgSO}_{4}$. The crude product was purified by flash column chromatography (hexane-EtOAc, 4:1 v/v) to give 15.

Yield: $482 \mathrm{mg}$ (91\%); brown solid; $R_{f} 0.81$ (hexane-EtOAc, $1: 1 \mathrm{v} / \mathrm{v}$ ); $R_{f}$ 0.53 (hexane-EtOAc, 3:1 v/v).

LC-MS (ESI): $m / z=314\left(\mathrm{C}_{18} \mathrm{H}_{24} \mathrm{NO}_{2} \mathrm{Si}\right)[\mathrm{M}+\mathrm{H}]^{+}$. 
To TMS-protected coumarin 15 (197 mg, $0.63 \mathrm{mmol}, 1$ equiv) was added TBAF ( $1 \mathrm{M}$ in THF, $1.26 \mathrm{~mL}, 1.26 \mathrm{mmol}$, 2 equiv) and the mixture was stirred at r.t. for 2 hours. The reaction mixture was concentrated onto Celite and purified by flash column chromatography $(0 \rightarrow 2 \% \mathrm{MeOH}-\mathrm{DCM})$ to give the product 16. It is important to note that $\mathbf{1 6}$ quickly decomposed and was used immediately in the next step.

Yield: $40 \mathrm{mg}$ (26\%); yellow-brownish oil; $R_{f} 0.20$ (DCM).

LC-MS (ESI): $m / z=242\left(\mathrm{C}_{15} \mathrm{H}_{16} \mathrm{NO}_{2}\right)[\mathrm{M}+\mathrm{H}]^{+}$.

\section{7-(Diethylamino)-3-((6-methyl-2-oxo-2H-pyran-4-yl)ethynyl)cou- marin (4)}

In a round-bottom flask, 8 (36 mg, $0.138 \mathrm{mmol}, 1$ equiv), $\mathrm{Pd}\left(\mathrm{PPh}_{3}\right)_{2} \mathrm{Cl}_{2}$ (5.0 mg, $0.007 \mathrm{mmol}, 0.05$ equiv), and $\mathrm{CuI}(3.0 \mathrm{mg}, 0.014 \mathrm{mmol}, 0.1$ equiv) were mixed and flushed with $\mathrm{N}_{2}$. Then coumarin $16(40 \mathrm{mg}$, $0.16 \mathrm{mmol}, 1.2$ equiv) dissolved in anhydrous acetonitrile $(5 \mathrm{~mL})$ was added, followed by EDIPA ( $96 \mu \mathrm{L}, 0.552 \mathrm{mmol}, 4$ equiv). The reaction mixture was stirred at $45^{\circ} \mathrm{C}$ for $1 \mathrm{~h}$, then the solvent was evaporated and the crude product was purified by flash column chromatography $(0 \rightarrow 3 \% \mathrm{DCM}-\mathrm{MeOH})$ to give the desired product.

Yield: $48 \mathrm{mg}$ (quant.); off-white solid; $R_{f} 0.35$ (hexane-EtOAc, 1:1 $\mathrm{v} / \mathrm{v})$.

IR (neat): 2969, 2931, 2192, 1708, 1578, 1513, 1414, 1280, 1134, 816 $\mathrm{cm}^{-1}$.

${ }^{1} \mathrm{H} \mathrm{NMR}\left(\mathrm{CDCl}_{3}, 500 \mathrm{MHz}\right): \delta=7.83(\mathrm{~s}, 1 \mathrm{H}), 7.27(\mathrm{~d}, J=8.9 \mathrm{~Hz}, 1 \mathrm{H})$, $6.62(\mathrm{dd}, J=8.9,2.5 \mathrm{~Hz}, 1 \mathrm{H}), 6.49(\mathrm{~d}, J=2.5 \mathrm{~Hz}, 1 \mathrm{H}), 6.27(\mathrm{~s}, 1 \mathrm{H}), 6.08$ $(\mathrm{t}, J=1.0 \mathrm{~Hz}, 1 \mathrm{H}), 3.45$ (q, $J=7.1 \mathrm{~Hz}, 4 \mathrm{H}), 2.24$ (d, J=1.0 Hz, $3 \mathrm{H}), 1.24$ (t, $J=7.1 \mathrm{~Hz}, 6 \mathrm{H})$.

${ }^{13} \mathrm{C}$ NMR $\left(\mathrm{CDCl}_{3}, 126 \mathrm{MHz}\right): \delta=162.4,161.9,157.1,152.2,147.9$, 138.9, 129.8, 113.9, 109.8, 108.4, 105.5, 97.4, 94.8, 89.5, 45.2, 20.0, 12.6.

HRMS (ESI): $m / z[\mathrm{M}+\mathrm{H}]^{+}$calcd for $\mathrm{C}_{21} \mathrm{H}_{20} \mathrm{NO}_{4}$ : 350.1392; found: 350.1386 .

\section{7-(Diethylamino)coumarin-3-carbaldehyde (17)}

Synthesized as described in the literature. ${ }^{12}$

$\mathrm{POCl}_{3}\left(4.7 \mathrm{~mL}, 50.4 \mathrm{mmol}, 3.1\right.$ equiv) under $\mathrm{N}_{2}$ atmosphere in a round-bottom flask was cooled to $0{ }^{\circ} \mathrm{C}$ in an ice-water bath and anhydrous DMF (4.8 mL, $61.8 \mathrm{mmol}, 3.8$ equiv) was added dropwise and the mixture was stirred for 30 minutes. Then 7-(diethylamino)coumarin (13; $3.53 \mathrm{~g}, 16.2 \mathrm{mmol}, 1$ equiv) was dissolved in anhydrous DMF $(20 \mathrm{~mL})$ and slowly added. The reaction mixture was stirred at $60{ }^{\circ} \mathrm{C}$ for 16 hours, then poured onto ice and the $\mathrm{pH}$ was adjusted to 6 with $20 \% \mathrm{NaOH}$ solution. The precipitate was filtered, washed with cold EtOH, then recrystallized from abs. EtOH to give the product.

Yield: $2.16 \mathrm{~g}$ (54\%); orange powder; $R_{f} 0.52$ (hexane-EtOAc, $1: 1 \mathrm{v} / \mathrm{v}$ ); $R_{f} 0.18$ (hexane-EtOAc, $3: 1 \mathrm{v} / \mathrm{v}$ ).

${ }^{1} \mathrm{H} \mathrm{NMR}\left(\mathrm{CDCl}_{3}, 500 \mathrm{MHz}\right): \delta=10.14(\mathrm{~s}, 1 \mathrm{H}), 8.26(\mathrm{~s}, 1 \mathrm{H}), 7.41(\mathrm{~d}, J=$ $9.0 \mathrm{~Hz}, 1 \mathrm{H}), 6.64(\mathrm{dd}, J=9.0,2.5 \mathrm{~Hz}, 1 \mathrm{H}), 6.49$ (d, $J=2.5 \mathrm{~Hz}, 1 \mathrm{H}), 3.48$ $(\mathrm{q}, J=7.2 \mathrm{~Hz}, 4 \mathrm{H}), 1.26(\mathrm{t}, J=7.2 \mathrm{~Hz}, 6 \mathrm{H})$.

LC-MS (ESI): $m / z=246\left(\mathrm{C}_{14} \mathrm{H}_{16} \mathrm{NO}_{3}\right)[\mathrm{M}+\mathrm{H}]^{+}$.

\section{7-(Diethylamino)-3-vinyl-coumarin (18)}

Methyltriphenylphosphonium bromide (464 mg, $1.30 \mathrm{mmol}, 1.3$ equiv) was dissolved in anhydrous THF ( $4 \mathrm{~mL}$ ) under $\mathrm{N}_{2}$, cooled to $0^{\circ} \mathrm{C}$ and $n$-BuLi (2.5 M in hexane, $0.65 \mathrm{~mL}, 1.30 \mathrm{mmol}, 1.3$ equiv) was added dropwise, then stirred for 20 minutes. Compound 17 (245 mg, 1.00 mmol, 1 equiv) was dissolved in anhydrous THF $(3 \mathrm{~mL})$ and added dropwise to the above reaction mixture at $0{ }^{\circ} \mathrm{C}$, then stirred at $25{ }^{\circ} \mathrm{C}$ for 18 hours. The reaction was quenched with sat. $\mathrm{NH}_{4} \mathrm{Cl}(50 \mathrm{~mL})$ and extracted with EtOAc $(3 \times 50 \mathrm{~mL})$ and dried with brine and $\mathrm{MgSO}_{4}$ to give the product. It should be noted that $\mathbf{1 8}$ quickly decomposes on dry silica and in the fridge over time.

Yield: $115 \mathrm{mg}$ (47\%); off-white sticky solid; $R_{f} 0.57$ (hexane-EtOAc, $3: 1 \mathrm{v} / \mathrm{v})$.

${ }^{1} \mathrm{H}$ NMR $\left(\mathrm{CDCl}_{3}, 500 \mathrm{MHz}\right): \delta=7.53(\mathrm{~s}, 1 \mathrm{H}), 7.22(\mathrm{~d}, J=8.8 \mathrm{~Hz}, 1 \mathrm{H})$, 6.64 (dd, $J=17.6,11.3 \mathrm{~Hz}, 1 \mathrm{H}), 6.54$ (dd, $J=8.8,2.5 \mathrm{~Hz}, 1 \mathrm{H}), 6.44$ (d, $J=2.5 \mathrm{~Hz}, 1 \mathrm{H}$ ), 5.99 (dd, $J=17.6,1.3 \mathrm{~Hz}, 1 \mathrm{H}$ ), 5.26 (dd, $J=11.3,1.3 \mathrm{~Hz}$, $1 \mathrm{H}), 3.37(\mathrm{q}, J=7.1 \mathrm{~Hz}, 4 \mathrm{H}), 1.17(\mathrm{t}, J=7.1 \mathrm{~Hz}, 6 \mathrm{H})$.

${ }^{13} \mathrm{C}$ NMR $\left(\mathrm{CDCl}_{3}, 126 \mathrm{MHz}\right): \delta=161.3,155.8,150.6,138.6,131.2$, $128.9,117.9,115.7,109.1,108.8,97.1,44.8,12.5$.

HRMS (ESI): $m / z[M+H]^{+}$calcd for $\mathrm{C}_{15} \mathrm{H}_{18} \mathrm{NO}_{2}: 244.1338$; found: 244.1336.

\section{(E)-7-(Diethylamino)-3-(2-(6-methyl-2-oxo-2H-pyran-4-yl)vi- nyl)coumarin (5)}

Compound 18 ( $75 \mathrm{mg}, 0.30 \mathrm{mmol}, 2$ equiv) and 8 ( $39 \mathrm{mg}, 0.15 \mathrm{mmol}$, 1 equiv) were dissolved in abs. $\mathrm{DMF}(2 \mathrm{~mL})$ under $\mathrm{N}_{2} . N, N$-Dicyclohexylmethylamine ( $130 \mu \mathrm{L}, 0.60 \mathrm{mmol}, 4$ equiv), QPhos ( $11 \mathrm{mg}, 0.015$ mmol, 0.1 equiv) and $\mathrm{Pd}_{2}(\mathrm{dba})_{3}(14 \mathrm{mg}, 0.015 \mathrm{mmol}, 0.1$ equiv) were added and the reaction mixture was heated in a microwave reactor at $100{ }^{\circ} \mathrm{C}$ for 1 hour. The solvent was evaporated in vacuo and the crude product was purified by flash chromatography $(0 \rightarrow 100 \%$, EtOAchexane) to give the desired product.

Yield: $17 \mathrm{mg}$ (32\%); orange solid; $R_{f} 0.38$ (hexane-EtOAc, $1: 1 \mathrm{v} / \mathrm{v}$ ). IR (neat): 3114, 2923, 1705, 1651, 1626, 1528, 1444, 1363, 1250, $1141,841 \mathrm{~cm}^{-1}$.

${ }^{1} \mathrm{H} \mathrm{NMR}\left(\mathrm{CDCl}_{3}, 500 \mathrm{MHz}\right): \delta=7.75(\mathrm{~s}, 1 \mathrm{H}), 7.31(\mathrm{~d}, J=8.9 \mathrm{~Hz}, 1 \mathrm{H})$, $7.17(\mathrm{~s}, 2 \mathrm{H}), 6.61(\mathrm{dd}, J=8.9,2.6 \mathrm{~Hz}, 1 \mathrm{H}), 6.50(\mathrm{~d}, J=2.6 \mathrm{~Hz}, 1 \mathrm{H}), 6.26$ $(\mathrm{s}, 1 \mathrm{H}), 6.08(\mathrm{~s}, 1 \mathrm{H}), 3.45$ (q, J = 7.1 Hz, $4 \mathrm{H}), 2.27$ (s, $3 \mathrm{H}), 1.24(\mathrm{t}, J=$ $7.1 \mathrm{~Hz}, 6 \mathrm{H})$.

${ }^{13} \mathrm{C}$ NMR $\left(\mathrm{CDCl}_{3}, 126 \mathrm{MHz}\right): \delta=163.9,161.3,156.5,152.3,151.7$, 142.8, 141.2, 136.4, 131.3, 129.8, 125.3, 115.7, 109.7, 109.1, 100.9, 97.3, 45.2, 20.2, 12.6 .

HRMS (ESI): $m / z[M+H]^{+}$calcd for $\mathrm{C}_{21} \mathrm{H}_{22} \mathrm{NO}_{4}$ : 352.1549; found: 352.1549 .

\section{Methyl 3-Bromo-2-oxo-2H-pyran-5-carboxylate (19)}

Pyridinium bromide perbromide (PBPB; $2.16 \mathrm{~g}, 6.76 \mathrm{mmol}, 1.3$ equiv) was dissolved in glacial acetic acid $(60 \mathrm{~mL})$ and heated to $100{ }^{\circ} \mathrm{C}$. Meanwhile methyl coumalate ( $800 \mathrm{mg}, 5.20 \mathrm{mmol}, 1$ equiv) was dissolved in glacial acetic acid $(40 \mathrm{~mL})$ and added dropwise to the hot solution. The reaction mixture was stirred at $100{ }^{\circ} \mathrm{C}$ for further 12 hours, then cooled to r.t. and most of the acetic acid was removed on a rotary evaporator. Water $(200 \mathrm{~mL})$ was added, the mixture was extracted with EtOAc $(3 \times 100 \mathrm{~mL})$, and the combined organic phases were washed with brine and dried over $\mathrm{MgSO}_{4}$. The crude product was purified by flash chromatography $(0 \rightarrow 30 \%$, EtOAc-hexane) to give the product.

Yield: $484 \mathrm{mg}$ (41\%); off-white solid; $R_{f} 0.68$ (hexane-EtOAc, $1: 1 \mathrm{v} / \mathrm{v}$ ). IR (neat): 3075, 2961, 1744, 1707, 1436, 1283, 1103, 955, $857 \mathrm{~cm}^{-1}$.

${ }^{1} \mathrm{H} \mathrm{NMR}\left(\mathrm{CDCl}_{3}, 500 \mathrm{MHz}\right): \delta=8.26(\mathrm{~d}, J=2.2 \mathrm{~Hz}, 1 \mathrm{H}), 8.13(\mathrm{~d}, J=2.2$ $\mathrm{Hz}, 1 \mathrm{H}), 3.87$ (s, $3 \mathrm{H})$.

${ }^{13} \mathrm{C} \mathrm{NMR}\left(\mathrm{CDCl}_{3}, 126 \mathrm{MHz}\right): \delta=162.5,156.8,156.6,142.7,112.9$, 111.7, 52.9. 
LC-MS (ESI): $m / z=233$ and $235\left(\mathrm{C}_{7} \mathrm{H}_{6} \mathrm{BrO}_{4}\right)[\mathrm{M}+\mathrm{H}]^{+}$.

HRMS (ESI): did not ionize.

\section{Methyl (E)-3-(2-(7-(Diethylamino)-coumarin-3-yl)vinyl)-2-oxo- 2H-pyran-5-carboxylate (6)}

Compound 18 ( $84 \mathrm{mg}, 0.34 \mathrm{mmol}, 2$ equiv) and 19 ( $40 \mathrm{mg}, 0.17 \mathrm{mmol}$, 1 equiv) were dissolved in abs. DMF ( $4 \mathrm{~mL}$ ) under $\mathrm{N}_{2}$. $N, N$-Dicyclohexylmethylamine ( $146 \mu \mathrm{L}, 0.68 \mathrm{mmol}, 4$ equiv), QPhos (12 mg, 0.017 mmol, 0.1 equiv) and $\mathrm{Pd}_{2}(\mathrm{dba})_{3}(16 \mathrm{mg}, 0.017 \mathrm{mmol}, 0.1$ equiv) were added and the reaction mixture was heated in a microwave reactor at $100{ }^{\circ} \mathrm{C}$ for 1 hour. The solvent was evaporated in vacuo and the crude product was purified by flash column chromatography $(0 \rightarrow 20 \%$ EtOAc-hexane) to give the desired product.

Yield: $58 \mathrm{mg}$ (85\%); reddish brown solid; $R_{f} 0.55$ (hexane-EtOAc, 1:1 $\mathrm{v} / \mathrm{v})$.

IR (neat): 2975, 2931, 1714, 1603, 1589, 1509, 1412, 1134, 998, 733 $\mathrm{cm}^{-1}$.

${ }^{1} \mathrm{H} \mathrm{NMR}\left(\mathrm{CDCl}_{3}, 500 \mathrm{MHz}\right): \delta=8.20(\mathrm{~d}, J=2.2 \mathrm{~Hz}, 1 \mathrm{H}), 7.87(\mathrm{~d}, J=2.2$ $\mathrm{Hz}, 1 \mathrm{H}), 7.71(\mathrm{~s}, 1 \mathrm{H}), 7.62$ (d, $J=16.1 \mathrm{~Hz}, 1 \mathrm{H}), 7.49$ (d, $J=16.1 \mathrm{~Hz}, 1$ $\mathrm{H}), 7.29(\mathrm{~d}, J=8.8 \mathrm{~Hz}, 1 \mathrm{H}), 6.60(\mathrm{dd}, J=8.8,2.3 \mathrm{~Hz}, 1 \mathrm{H}), 6.50(\mathrm{~d}, J=2.3$ Hz, 1 H), 3.89 (s, $3 \mathrm{H}), 3.43$ (q, J = 7.1 Hz, $4 \mathrm{H}), 1.22$ (t, J= 7.1 Hz, $6 \mathrm{H})$.

${ }^{13} \mathrm{C}$ NMR $\left(\mathrm{CDCl}_{3}, 126 \mathrm{MHz}\right): \delta=163.7,161.1,159.8,156.0,154.9$, 151.1, 141.1, 135.7, 129.7, 129.4, 124.3, 123.3, 116.9, 113.0, 109.5, 97.2, 52.6, 45.1, 12.6 .

HRMS (ESI): $m / z[M+H]^{+}$calcd for $\mathrm{C}_{22} \mathrm{H}_{22} \mathrm{NO}_{6}$ : 396.1447; found: 396.1441 .

\section{7-(Diethylamino)-3-((1-(hydroxymethyl)-7-methyl-1a,2,3,8,9,9a- hexahydro-1H-benzo[a]cyclopropa[ $e][8]$ annulen-5-yl)ethynyl)- coumarin (4-BCN)}

In a round-bottom flask 4 ( $20 \mathrm{mg}, 0.057 \mathrm{mmol}, 1$ equiv) was dissolved in acetonitrile $(5 \mathrm{~mL})$ and $\mathrm{BCN}(17 \mathrm{mg}, 0.114 \mathrm{mmol}, 2$ equiv) was added. The reaction mixture was stirred at $40{ }^{\circ} \mathrm{C}$ for 6 hours, then 2.5 days at $25^{\circ} \mathrm{C}$. After concentration onto silica, the crude product was purified by flash column chromatography $(0 \rightarrow 60 \%$, EtOAc-hexane) to give the desired product.

Yield: $23 \mathrm{mg}$ (88\%); bright-yellow, sticky solid; $R_{f} 0.21$ (hexane-EtOAc, $1: 1 \mathrm{v} / \mathrm{v})$.

IR (neat): 3414, 2970, 2924, 1716, 1614, 1516, 1254, 1131, 1014, $727 \mathrm{~cm}^{-1}$.

${ }^{1} \mathrm{H} \mathrm{NMR}\left(\mathrm{CDCl}_{3}, 500 \mathrm{MHz}\right): \delta=7.78(\mathrm{~s}, 1 \mathrm{H}), 7.29(\mathrm{~d}, J=8.9 \mathrm{~Hz}, 1 \mathrm{H})$, $7.26(\mathrm{~s}, 1 \mathrm{H}), 7.22(\mathrm{~s}, 1 \mathrm{H}), 6.61(\mathrm{dd}, J=8.9,2.1 \mathrm{~Hz}, 1 \mathrm{H}), 6.53(\mathrm{~d}, J=2.1$ $\mathrm{Hz}, 1 \mathrm{H}), 3.76(\mathrm{~m}, 2 \mathrm{H}), 3.46(\mathrm{q}, J=7.1 \mathrm{~Hz}, 4 \mathrm{H}), 3.02(\mathrm{~m}, 1 \mathrm{H}), 2.96(\mathrm{~m}$, $1 \mathrm{H}), 2.81(\mathrm{~m}, 2 \mathrm{H}), 2.34(\mathrm{~s}, 3 \mathrm{H}), 2.32-2.21(\mathrm{~m}, 2 \mathrm{H}), 1.71(\mathrm{~s}, 1 \mathrm{H}), 1.64$ (m, 2 H), 1.60-1.44 (m, 2 H), 1.25 (t, J = 7.1 Hz, 6 H), 1.11 (m, 2 H).

${ }^{13} \mathrm{C} \mathrm{NMR}\left(\mathrm{CDCl}_{3}, 126 \mathrm{MHz}\right): \delta=161.1,156.3,151.1,145.0,136.1$, 131.7, 131.2, 128.9, 125.2, 119.9, 110.1, 109.3, 108.7, 105.4, 97.6, 94.1, 83.7, 60.0, 45.1, 34.0, 32.4, 26.6, 23.6, 20.0, 12.6 .

HRMS (ESI): $m / z[\mathrm{M}+\mathrm{H}]^{+}$calcd for $\mathrm{C}_{30} \mathrm{H}_{34} \mathrm{NO}_{3}$ : 456.2539; found: 456.2531 .

\section{Activation and Conjugation of Transferrin for SDS-PAGE and In- Gel Fluorescence Study}

Human Transferrin (TF, $70 \mu \mathrm{M}$ ) and BCN-NHS (350 $\mu \mathrm{M}$; from $20 \mathrm{mM}$ stock solution in DMSO) were mixed and incubated for $60 \mathrm{~min}$ at r.t. in $110 \mathrm{mM} \mathrm{Na}_{2} \mathrm{CO}_{3} / \mathrm{NaHCO}_{3}$ buffer ( $\mathrm{pH} 9.0$ ). The excess reagents were removed by using a SpinPrep column (Sigma, St Louis, MO, USA) filled with Sephadex G-25 'Fine' desalting gel (Pharmacia Fine Chemicals, Sweden). This procedure resulted in a buffer exchange also to $\mathrm{PBS}(\mathrm{pH}$ 7.4). In the next step, $4(500,250$ or $125 \mu \mathrm{M})$ was added and co-incubated for 24 hours. The excess reagents were removed again by using a SpinPrep column filled with Sephadex G-25 'Fine' desalting gel. The labeled proteins were subjected to sodium dodecyl-sulfate polyacrylamide gel electrophoresis (SDS-PAGE).

\section{SDS Polyacrylamide Gel Electrophoresis and In-Gel Fluorescence Detection}

The samples were diluted with a sample buffer $(250 \mathrm{mM}$ Tris- $\mathrm{HCl}$ (pH 6.8), $10 \%$ SDS, $40 \%$ glycerol, $0.02 \%$ bromophenol blue, $400 \mathrm{mM} \mathrm{DTT}$ ) in a 3:1 ratio. The size of the polyacrylamide gels was $8.5 \mathrm{~cm} \times 7.5 \mathrm{~cm} \times$ $0.1 \mathrm{~cm}$. They were the combination of $4 \%$ concentration and $8 \%$ separation PAGE gels (acrylamide/bisacrylamide ratio was 29:1; and concentration gel buffer was $125 \mathrm{mM}$ Tris- $\mathrm{HCl}+0.1 \% \mathrm{SDS}$ (pH 6.8) and the separation gel buffer was $375 \mathrm{mM}$ Tris- $\mathrm{HCl}+0.1 \% \mathrm{SDS}(\mathrm{pH} 8.8)$ ). PageRuler Plus Prestained Protein Ladder (Thermo Fisher Scientific) was applied as the molecular weight standard. Separations were carried out in a Mini-Protean Tetra Cell (Bio-Rad, Hercules, CA, USA) using $25 \mathrm{mM}$ Tris $/ 192 \mathrm{mM}$ glycine $+0.1 \% \mathrm{SDS}$ (pH 8.3) as the running buffer and $150 \mathrm{~V}$ voltage for $70 \mathrm{~min}$ at $25^{\circ} \mathrm{C}$.

The gels were documented by using a Biorad Bio-Rad ChemiDoc ${ }^{\mathrm{TM}}$ Imager. 4/4-BCN fluorescence was detected in the Pro-Q Emerald 488 channel using blue led epi illumination (460-490 nm) and emission detection with a 532/28 $\mathrm{nm}$ band pass filter. Afterwards, the gels were stained for proteins with Coomassie Brilliant-Blue and documented using the colorimetric setting with white epi illumination.

\section{Conflict of Interest}

The authors declare no conflict of interest.

\section{Funding Information}

This work has been implemented with the support provided by the Ministry of Innovation and Technology of Hungary from the National Research, Development and Innovation Fund, financed under the [NKFIH-K-131439 and NKFIH-PD-123955] funding scheme. We are also grateful for the generous support of Eötvös Loránd Research Network (KEP-6, FIKU).

\section{Acknowledgment}

The authors would like to thank Ágnes Gömöry (MS Proteomics Research Group, Research Centre for Natural Sciences, Magyar tudósok krt 2., H-1117, Budapest, Hungary) for the high-resolution mass spectrometry (HRMS) measurements. The authors would also like to thank Dr. Bianka Söveges for creating the graphical abstract content.

\section{Supporting Information}

Supporting information for this article is available online at https://doi.org/10.1055/a-1761-4672. 


\section{References}

(1) Scinto, S. L.; Bilodeau, D. A.; Hincapie, R.; Lee, W.; Nguyen, S. S.; Xu, M.; Ende, C. W.; Finn, M. G.; Lang, K.; Lin, Q.; Pezacki, J. P.; Prescher, J. A.; Robillard, M. S.; Fox, J. M. Nat. Rev. Methods Primers 2021, 1, 30.

(2) (a) Knall, A.-C.; Slugov, C. Chem. Soc. Rev. 2013, 42, 5131. (b) Kozma, E.; Demeter, O.; Kele, P. ChemBioChem 2017, 18, 486.

(3) (a) Meimetis, L. G.; Carlson, J. C. T.; Giedt, R. J.; Kohler, R. H.; Weissleder, R. Angew. Chem. Int. Ed. 2014, 53, 7531. (b) Wieczorek, A.; Werther, P.; Euchner, J.; Wombacher, R. Chem. Sci. 2017, 8, 1506. (c) Kozma, E.; Kele, P. Org. Biomol. Chem. 2019, 17, 215. (d) Werther, P.; Yserentant, K.; Braun, F.; Kaltwasser, N.; Popp, C.; Baalmann, M.; Herten, D.-P.; Wombacher, R. Angew. Chem. Int. Ed. 2020, 59, 804. (e) Werther, P.; Yserentant, K.; Braun, F.; Grußmayer, K.; Navikas, V.; Yu, M.; Zhang, Z.; Ziegler, M. J.; Mayer, C.; Gralak, A. J.; Busch, M.; Chi, W.; Rominger, F.; Radenovic, A.; Liu, X.; Lemke, E. A.; Buckup, T.; Herten, D.-P.; Wombacher, R. ACS Cent. Sci. 2021, 7, 1561. (f) Albitz, E.; Kern, D.; Kormos, A.; Bojtár, M.; Török, G.; Biró, A.; Szatmári, Á.; Németh, K.; Kele, P. Angew. Chem. Int. Ed. 2022, 61, e202111855.

(4) (a) Nikic, I.; Plass, T.; Schraidt, O.; Szymanski, J.; Briggs, J.; Schultz, C.; Lemke, E. A. Angew. Chem. Int. Ed. 2014, 53, 2245. (b) Szatmári, Á.; Cserép, G. B.; Molnár, T. Á.; Söveges, B.; Biró, A.; Várady, G.; Szabó, E.; Németh, K.; Kele, P. Molecules 2021, 26, 4988. (c) Ganz, D.; Harijan, D.; Wagenknecht, H.-A. RSC Chem. Biol. 2020, 1, 86.

(5) (a) Devaraj, N. K. ACS Cent. Sci. 2018, 4, 952. (b) Nguyen, S. S.; Prescher, J. A. Nat. Rev. Chem. 2020, 4, 476. (c) Kamber, D. N.; Liang, Y.; Blizzard, R. J.; Liu, F.; Mehl, R. A.; Houk, K. N.; Prescher, J. A. J. Am. Chem. Soc. 2015, 137, 8388. (d) Reisacher, U.; Ploschik, D.; Rönicke, F.; Cserép, G. B.; Kele, P.; Wagenknecht, H. A. Chem. Sci. 2019, 10, 4032. (e) Favre, C.; Friscourt, F. Org. Lett. 2018, 20, 4213. (f) Smeenk, M. L. W. J.; Agramunt, J.; Bonger, K. M. Curr. Opin. Chem. Biol. 2021, 60, 79. (g) Narayanam, M. K.; Liang, Y.; Houk, K. N.; Murphy, J. M. Chem. Sci. 2016, 7, 1257.

(6) (a) Diels, O.; Alder, K. Justus Liebigs Ann. Chem. 1931, 490, 257. (b) Afarinkia, K.; Vinader, V.; Nelson, T. D.; Posner, G. H. Tetrahedron 1992, 48, 9111. (c) Dobler, D.; Leitner, M.; Moor, N.; Reiser, O. Eur. J. Org. Chem. 2021, 6180.

(7) Varga, B. R.; Kállay, M.; Hegyi, K.; Béni, S.; Kele, P. Chem. Eur. J. 2012, 18, 822
(8) (a) Knorr, G.; Kozma, E.; Schaart, J. M.; Németh, K.; Török, G.; Kele, P. Bioconjugate Chem. 2018, 29, 1312. (b) Egyed, A.; Kormos, A.; Söveges, B.; Németh, K.; Kele, P. Bioorg. Med. Chem. 2020, 28, 115218. (c) Németh, E.; Knorr, G.; Németh, K.; Kele, P. Biomolecules 2020, 20, 397.

(9) (a) Lee, J. J.; Pollock, G. R. III.; Mitchell, D.; Kasuga, L.; Kraus, G. A. RSC Adv. 2014, 4, 45657. (b) Cai, Q. Chin. J. Chem. 2019, 37, 946. (c) Cole, C. J. F.; Fuentes, L.; Snyder, S. A. Chem. Sci. 2020, 11, 2175.

(10) (a) Fairlamb, I. J. S.; Lu, F. J.; Schmidt, J. P. Synthesis 2003, 2564. (b) Fairlamb, I. J. S.; Lee, A. F.; Loe-Mie, F. E. M.; Niemelä, E. H.; O'Brien, C. T.; Whitwood, A. C. Tetrahedron 2005, 61, 9827. (c) Frébault, F.; Oliveira, M. T.; Wöstefeld, E.; Maulide, N. J. Org. Chem. 2010, 75, 7962. (d) Xavier, T.; Pichon, C.; Presset, M.; Gall, E. L.; Condon, S. Eur. J. Org. Chem. 2021, 4308.

(11) Mukhopadhyay, A.; Maka, V. K.; Moorthy, J. N. Phys. Chem. Chem. Phys. 2017, 19, 4758.

(12) Wu, J.-S.; Liu, W.-M.; Zhuang, X.-Q.; Wang, F.; Wang, P.-F.; Tao, S.-L.; Zhang, X.-H.; Wu, S.-K.; Lee, S.-T. Org. Lett. 2007, 9, 33.

(13) (a) Wu, W.; Kolanowski, J. L.; Boumelhem, B. B.; Yang, K.; Lee, R.; Kaur, A.; Fraser, S. T.; New, E. J.; Rendina, L. M. Chem. Asian J. 2017, 12, 1704. (b) Sun, H.; Guo, H.; Wu, W.; Liu, X.; Zhao, J. Dalton Trans. 2011, 7834.

(14) Ashworth, I. W.; Bowden, M. C.; Dembofsky, B.; Levin, D.; Moss, W.; Robinson, E.; Szczur, N.; Virica, J. Org. Process Res. Dev. 2003, $7,74$.

(15) (a) Cserép, G. B.; Herner, A.; Kele, P. Methods Appl. Fluoresc. 2015, 3, 042001. (b) Deb, T.; Tu, J.; Franzini, R. M. Chem. Rev. 2021, 121, 6850. (c) Codelli, J. A.; Baskin, J. M.; Agard, N. J.; Bertozzi, C. R. J. Am. Chem. Soc. 2008, 130, 11486. (d) Dommerholt, J.; Schmidt, S.; Temming, R.; Hendriks, L. J. A.; Rutjes, F. P. J. T.; Van Hest, J. C. M.; Lefeber, D. J.; Friedl, P.; Van Delft, F. L. Angew. Chem. Int. Ed. 2010, 49, 9422.

(16) Rurack, K.; Spieles, M. Anal. Chem. 2011, 83, 1232.

(17) (a) Németh, E.; Knorr, G.; Németh, K.; Kele, P. Biomolecules 2020, 20, 397. (b) Török, G.; Cserép, G. B.; Telek, A.; Arany, D.; Váradi, M.; Homolya, L.; Kellermayer, M.; Kele, P.; Németh, K. Methods Appl. Fluoresc. 2021, 9, 015006.

(18) (a) Wu, H.; Yang, J.; Seckute, J.; Deveraj, N. K. Angew. Chem. Int. Ed. 2014, 53, 5805. (b) Lambert, W. D.; Fang, Y.; Mahapatra, S.; Huang, Z.; Ende, C. W.; Fox, J. M. J. Am. Chem. Soc. 2019, 141, 17068 . 